\title{
İlişkisel ve İşlemsel Psikolojik Sözleşmede Algılanan İhlalin İşten Ayrılma Niyeti ve Algılanan Örgütsel Destek Üzerindeki Etkisi
}

\author{
The Effect of Relational and Transactional Psychological Contract Breach on Turnover \\ Intention and Perceived Organizational Support
}

Ozan BÜYÜKYILMAZ'1, Ahmet F. ÇAKMAK²

\begin{abstract}
ÖZET
Bu çalışmanın amacl, psikolojik sözleşmelerin iki türü olan ilişkisel ve işlemsel sözleşmelerde algılanan ihlalin, işten ayrılma niyeti ve algılanan örgütsel destek üzerindeki etkisini belirleyebilmektir. Bu amaç kapsamında, Türkiye'de yer alan devlet ve vakıf üniversitelerinde görev yapan 570 akademik personelden anket yöntemi kullanılarak veriler elde edilmiştir. Hipotezleri test etmek amacıyla hiyerarşik regresyon analizinden yararlanılmıştır. Çalışmanın sonucunda, ilişkisel psikolojik sözleşmede algılanan ihlalin, işten ayrılma niyetini artırıcı ve algılanan örgütsel desteği azaltıcı bir etkisinin bulunduğu belirlenmiştir. İşlemsel psikolojik sözleşme algılanan ihlalin ise işten ayrılma niyeti üzerinde anlamlı bir etkisinin bulunmadığı, fakat yalnızca işlemsel sözleşmenin faydalar boyutunda algılanan ihlalin, algılanan örgütsel desteği azaltıcı bir etkisinin bulunduğu tespit edilmiştir.
\end{abstract}

Anahtar Kelimeler: Psikolojik sözleşme ihlali, işten ayrılma niyeti, algılanan örgütsel destek, akademik personel

\section{GíRiş}

Teknolojideki değişim, yeniden yapılanma, küresel büyüme, örgütsel küçülme ve bu unsurlara bağlı olarak değişen istihdam ilişkileri ve bireyselleşme, ilk olarak 1960'lı yıllarda kullanılmaya başlanan (Argyris, 1960; Levinson vd., 1962; Schein, 1965) psikolojik sözleşme kavramının örgüt yaşamında öneminin artması sonucunu doğurmuştur. Bu çerçevede 1990'lı yılların başından itibaren örgütsel davranış ve örgütsel psikoloji alanında psikolojik sözleşmelere ilişkin gerçekleştirilen çalışmaların sayısının arttığı görülmektedir (Anderson ve Schalk, 1998; Conway ve Briner, 2005; Coyle-Shapiro ve Kessler, 2002; Guest, 2004; Robinson vd., 1994; Rousseau, 1989; Shore ve Tetrick, 1994).

Psikolojik sözleşmelerin hem örgütler hem de araştırmacılar tarafından önemli bir kavram olarak görülmesinin temel nedeni, psikolojik sözleşme kapsamında vaatlerin ve vaatler sonucunda ortaya çıkan

\begin{abstract}
The purpose of this study is to determine the effect of relational and transactional psychological contract breach on turnover intention and perceived organizational support. For this purpose data for the sample was collected from 570 academicians from state and foundation universities in Turkey via survey method. Hierarchical regression analyses were conducted to test the hypotheses. The results show that relational psychological contract breach had an increasing effect on turnover intention and had a reducing effect on perceived organizational support. On the other hand, transactional psychological contract breach had an insignificant effect on turnover intention, but only the benefits dimension of transactional psychological contract had a reducing effect on perceived organizational support.
\end{abstract}

Keywords: Psychological contract breach, turnover intention, perceived organizational support, academic staff

yükümlülüklerin yerine getirilmesine çalışanın olumlu tutum ve davranışlarla karşılık vereceğinin çeşitli araştırmalar tarafından ortaya konulmasıdır (Conway ve Coyle-Shapiro, 2012; Turnley vd., 2003). Fakat her zaman için vaatlerin ve bu kapsamda ortaya çıkan yükümlülüklerin yerine getirilmesi mümkün olmamaktadır. Psikolojik sözleşmeler kapsamında yerine getirilmemiş vaatler, psikolojik sözleşme ihlali kavramı altında incelenmektedir.

İstihdam ilişkisi çerçevesinde psikolojik sözleşme ihlalinin sürekli karşılaşılan bir durum olduğu görülmektedir ve çalışan ve örgüt arasındaki ilişkiye kalıcı zararlar verebilmektedir. Gerçekleştirilen araştırmalar, algılanan psikolojik sözleşme ihlali sonucunda çalışanın işinden duyduğu tatmin seviyesinin düştüğünü (Robinson ve Rousseau, 1994), örgüte bağlılık seviyesinde bir azalma meydana geldiğini (Cassar ve Briner, 2011), algıladığı örgütsel desteğin azaldığını (Coyle- 
Shapiro ve Kessler, 2000; Kiewitz vd., 2009) ve çalıştığı örgütten ayrılmak istediğini ortaya koymaktadır (Robinson ve Rousseau, 1994; Turnley ve Feldman, 2000).

Bununla birlikte psikolojik sözleşme ihlalinin tutum ve davranışlar üzerindeki olumsuz etkisinin çoğunlukla bankalar, oteller, hastaneler gibi farklı sektörlerde görev yapan çalışanlar üzerinde araştırıldığı görülmektedir. Buna karşılık literatürde, üniversitelerde görev yapan akademik personelin sahip olduğu psikolojik sözleşmelere ilişkin sınırlı sayıda çalışma bulunmaktadır (Aydın vd., 2008; Dabos ve Rousseau, 2004; Orvis vd., 2008). Dolayısıyla akademik personel için geçerli psikolojik sözleşmelerin hangi unsurları kapsadığına ve bu unsurların ne derece yerine getirildiğine ilişkin çok fazla güncel bilgi bulunmamaktadır.

Belirtilen olgulardan hareketle bu çalışma, örgüt tarafından yerine getirilmeyen vaatlerin çalışan tutumları üzerindeki olumsuz etkilerine odaklanmaktadır. Daha spesifik olarak bu çalışma ile, psikolojik sözleşmesinin maddi ve manevi unsurlarında ihlal algılaması sonucunda, akademik personelin işinden ayrılma isteğinde bir artış olup olmayacağı ve üniversitesinin kendisine verdiği desteği algılayış derecesinde bir azalış meydana gelip gelmeyeceği araştırılmaktadır.

\section{KURAMSAL ÇERÇEVE}

\subsection{Psikolojik Sözleşme ve Psikolojik Sözleşme inhlali}

Psikolojik sözleşme kavramı, hızlı değişimlerin yaşandığı örgütsel çevrede, modern iş hayatını ve istihdam ilişkilerini anlayabilmek amacıyla kullanılabilecek bütünleştirici bir kavram olarak ele alınmaktadır. (Anderson ve Schalk, 1998:639; Conway ve Briner, 2005:7; Guest, 1998:649; Robinson, 1996:41; Shore ve Tetrick, 1994:91; Turnley ve Feldman, 2000:25). Genel olarak bireyin, kendisi ve örgütü arasındaki mübadele ilişkisinin koşullarına dair oluşturduğu bireysel inanç sistemi (Rousseau, 1989:123; Rousseau, 1995:9) şeklinde tanımlanmakta olan psikolojik sözleşme kavramı, örgüt içerisindeki bireylerin tutum ve davranışlarını anlayabilmeye ve bu bireylerin farklı durumlarda ne tür tepkiler verebileceğine ilişkin öngörüde bulunabilmeye yardımcı olan bir araç durumundadır (Anderson ve Schalk, 1998:640). Psikolojik sözleşmeler, örgüt içindeki bireyler arasında var olan fakat açık şekilde ortaya konulamayan anlaşmalara odaklanarak, istihdam ilişkisinin içeriğinin ve süreçlerinin daha kapsamlı olarak incelenebilmesine olanak sağlamaktadır (Guest, 2004:545).

Genel olarak psikolojik sözleşmelerin işlemsel ve ilişkisel olarak adlandırılan iki temel türü olduğu dü- şünülmektedir (Rousseau, 1995). Bu çerçevede işlemsel sözleşmeler ekonomik mübadele ile ilişkilendirilirken, ilişkisel sözleşmeler sosyal mübadele ile ilişkilendirilmektedir (Millward ve Hopkins, 1998:1531; Shore ve Tetrick, 1994:95).

İ̧̧lemsel sözleşmeler genel şekilde "çalışma ve ücret arasındaki adil ilişki" şeklinde ifade edilmektedir ve daha çok kısa dönemli ve ekonomik mübadeleye odaklanmaktadır (Rousseau, 1995:92). İşlemsel sözleşmeler, çalışanlara sağlanan ekonomik katkıları, çalışanın işe katılımına karşılık sınırlı teşvikleri, çalışan ve işveren arasındaki kısa dönemli ilişkiyi, iyi şekilde tanımlanmış çalışan yükümlülüklerini, karşılıklı yükümlülüklere ilişkin az esnekliği ve gerçekleştirilen işe ilişkin sınılı gelişimi kapsamaktadır (Grimmer ve Oddy, 2007:155; Petersitzke, 2009:30).

Illişkisel sözleşmeler ise, hem çalışanlar için (işletmeye özgü yeteneklerin kazanımı, uzun dönemli kariyer gelişimi) hem de işverenler için (yaygın eğitimler) önemli yükümlülükleri kapsar şekilde uzun dönemli bir ilişkiye odaklanmaktadır (Rousseau, 1995:91-92). İlişkisel sözleşmelerin yalnızca ekonomik değil, aynı zamanda duygusal ve bütünsel bir yapısı da bulunmaktadır. Bununla birlikte ilişkisel sözleşmelerde yükümlülüklerin yerine getirilmesi uzun zaman alabilmekte, yükümlülükler kısmen örtük olabilmekte ve sözleşme şartları kolayca değişebilmektedir (Petersitzke, 2009:30).

Psikolojik sözleşmeler kapsamında örgütün yükümlülüklerini yerine getirmesi, çalışanın tatmin olmasıyla, daha fazla ve istekli çalışmasıyla veya örgüte daha fazla bağlılık hissetmesiyle sonuçlanabilmektedir. Fakat sözleşme tarafları her zaman için verdikleri vaatleri ve yükümlülüklerini yerine getir(e)memektedir. Dolayısıyla da kendisine belirli bir konuda vaat verildiğini düşünen, fakat bu vaat çerçevesindeki yükümlülüklerin gerçekleşmediğini algılayan çalışanın durumu psikolojik sözleşme ihlali olarak adlandırılmaktadır (Kiefer ve Briner, 2006:204).

Psikolojik sözleşme ihlali, birçok araştırmacının önemle incelediği bir konu olmasına karşılık, üzerinde fikir birliğine varılamamıştır. Dolayısıyla da kavrama ilişkin gerçekleştirilen tanımlarda farklıııklar bulunmaktadır. Rousseau (1989:128) psikolojik sözleşme ihlalinin, "örgütün veya örgüt temsilcilerinin, gerçekleştirdiği katkıya karşılık olarak bireysel inançlar çerçevesinde oluşan örgütsel yükümlülüklerin yerine getirilmemesi" anlamına geldiğini belirtmektedir. Shore ve Tetrick (1994:102)'e göre ihlal, "çalışanın, sözleşme şartlarına ilişkin yükümlülüklerin yerine getirilmediği şeklinde örgütünden elde ettiği bilgi sonucunda ortaya çıkan tepkisel süreci" ifade etmek- 
tedir. Araştırmacılar tarafından daha fazla kullanıldığı şekliyle ise psikolojik sözleşme ihlali, "bireyin sahip olduğu psikolojik sözleşmesi kapsamında gerçekleştirdiği katkılarla orantılı olarak, örgütünün bir veya birkaç yükümlülüğünü yerine getirmediğine ilişkin sahip olduğu biliş durumu" şeklinde tanımlanmaktadır (Morrison ve Robinson, 1997:230).

Ampirik araştırmalar, genel olarak çalışanların yarısından fazlasının psikolojik sözleşmelerinin en az bir faktörüne ilişkin ihlal algısı yaşadığını ortaya koymaktadır (Grimmer ve Oddy, 2007; Robinson ve Rousseau, 1994; Turnley ve Feldman, 2000). Bu kapsamda ihlal algısının, nelerin yükümlülükler çerçevesinde algılandığı ile örgütsel gerçeklikler arasındaki uyuşmazlığın, birey tarafından gerçekleştirilen bilişsel bir değerlendirmesi olduğu görülmektedir (Petersitzke, 2009:41). Diğer bir ifadeyle ihlal algısı, örgütü ile mübadele ilişkisi içersinde bulunan bireyin, örgüt tarafından ortaya konulan vaatler ile elde ettikleri arasında gerçekleştirdiği değerlendirme temeline dayanmaktadır (Topa vd., 2008:488).

\section{2. İşten Ayrılma Niyeti}

Işten ayrılma niyeti, bireyin çalıştığı örgütten ayrılmaya bilinçli ve< planlı olarak karar vererek bunu sürekli olarak düşünmesi ve istemesi olarak ifade edilmektedir (Rusbult vd., 1988:601; Tett ve Meyer, 1993:262). Diğer bir tanıma göre ise işten ayrılma niyeti, bireyin isteyerek ve bilinçli olarak belirli bir zaman içerisinde içinde bulunduğu örgütten ayrılmayı arzu etmesidir (Cho vd., 2009:374).

Gerçekleştirilen araştırmalar, işten ayrılma niyetinin, personel devrinin güçlü bir belirleyicisi olduğunu göstermektedir (Iverson ve Deery, 1997; Tett ve Meyer, 1993). Steel ve Ovalle (1984) tarafından gerçekleştirilen çalışma, işten ayrılma niyeti ile personel devri arasında güçlü bir ilişki bulunduğunu ortaya koymakla kalmamakta, bununla birlikte, işten ayrılma niyeti ile personel devri arasındaki ilişkinin işten ayrılma niyeti ile diğer örgütsel faktörler arasındaki ilişkiden daha güçlü olduğunu da ispat etmektedir.

Gönüllü olarak olsun veya olmasın, bir çalışanın işinden ayrılması önemli sonuçlar ortaya çıkartabilmektedir. Bireyin işini bırakması, işe alım ve eğitim maliyetlerinde bir artışa neden olmakta, örgüt içerisinde kalan diğer çalışanların moralini azaltmakta, iş tatminini olumsuz etkilemekte ve müşteri tarafından algılanan hizmetin kalitesini düşürebilmektedir (Cho vd., 2009:374). Bununla birlikte çalışanın işinden ayrılması, çoğu zaman örgütün değerli bir işgörenini kaybetmesi anlamına gelmekte ve örgütsel faaliyetlerin belirli oranda kesintiye uğramasına neden olmaktadır (George ve Jones, 1996:318).

\subsection{Algılanan Örgütsel Destek}

Algılanan örgütsel destek, genel şekilde, örgütün çalışanına duyduğu bağlılığın çalışan tarafından algılanma derecesi olarak tanımlanmaktadır (Settoon vd., 1996:220; Shore ve Wayne, 1993:774; Wayne vd., 1997:83). Örgütsel destek teorisi, örgüt tarafından sağlanacak faydaların, çalışanların işe ilişkin çabasını arttıracağını ve duygusal ihtiyaçlarını karşılayacağını öne sürmektedir. Bu çerçevede örgütsel destek, örgüt değerlerinin çalışanların esenliğini dikkate alması ve onların mutluluklarını artırıcı nitelik taşıması durumunu ifade etmektedir (Eisenberger vd., 1986:501; Eisenberger vd., 2001:42).

Örgütsel destek teorisine göre algılanan örgütsel desteğin arka planında, çalışanların örgütü insan özellikleri çerçevesinde değerlendirme eğilimi yatmaktadır (Aselage ve Eisenberger, 2003:492). Örgütsel destek algılayan çalışan, sağladığı katkıya örgüt tarafından ne ölçüde değer verildiğine ve mutluluğunun ne kadar önemsendiğine ilişkin bir inanç geliştirmektedir (Eisenberger vd., 1997:812; Rhoades ve Eisenberger, 2002:698). Dolayısıyla örgütün kendisine yüksek oranda destek verdiğini düşünen bir çalışan, kendisini güvende hissetmekte ve ortaya çıkacak sorunlarda örgütün arkasında olduğunu bilmektedir.

İşverenler, genel olarak çalışanları, gösterdikleri sadakat ve bağlılık çerçevesinde değerlendirmektedir. Bu çerçevede duygusal bağlıığı yüksek olan çalışanların daha yüksek performans sergileyeceği düşünülmektedir (Eisenberger vd., 1986:500). Fakat diğer açıdan bakıldığında çalışanlar da benzer şekilde örgütlerinden bağlılık beklemektedir. Diğer bir ifadeyle, örgütün kendisini kabul ettiğini ve saygı gösterdiğini düşünen, ödül ve terfi imkanı olan, örgüt bilgilerine erişim imkanı verilen çalışanlar, kendilerine değer verildiğini hissetmekte ve işlerini daha iyi şekilde gerçekleştirmektedir (Rhoades ve Eisenberger, 2002:698).

\section{HIPOTEZLER VE ARAŞTIRMA MODELI}

Psikolojik sözleşme ihlallerine ilişkin gerçekleştirilen araştırmalarda, örgütün verdiği vaatleri yerine getirme konusunda başarısızlık göstermesinin çalışan tutumları ve davranışları üzerinde olumsuz etkilerinin olacağı saptanmıştır. Özellikle araştırmalar, psikolojik sözleşme ihlal algılanması durumunda çalışanların, istihdam ilişkisine devam etmenin kendilerine fayda sağlayıp sağlamadığını sorgulamaya başlayacağını belirtmektedir (Turnley ve Feldman, 1999). Bazı durumlarda ise çalışanlar, ihlal durumunun aşırı derecede adaletsiz olduğunu düşünerek veya kendilerine kötü davranıldığını düşünerek farklı örgütlerde iş aramaya karar vermektedir (Suazo vd., 2005). 
Robinson ve Rousseau (1994), psikolojik sözleşme ihlali algılayan çalışanların örgüte duydukları güvende ve iş tatmininde bir azalma olduğunu, işten ayrılma niyetlerinde ise bir artış olduğunu tespit etmiştir. Turnley ve Feldman (2000) tarafından gerçekleştirilen araştırma ile de psikolojik sözleşme ihlal algısının, çalışanın işi umursamaması veya işten ayrılmayı istemesi gibi çeşitli olumsuz sonuçlarının olabileceği belirlenmiştir. Bazı çalışmalarda ise ilişkisel sözleşmede algılanan ihlalin, işlemsel sözleşmede algılanan ihlale nazaran işten ayrılma niyeti üzerinde daha güçlü bir etkisinin bulunduğu ortaya konulmaktadır (Zhang vd., 2010; Zhao vd., 2007). Literatürdeki çalışmalar göz önünde bulundurularak, psikolojik sözleşme ihlal algısı ile işten ayrılma niyeti arasında pozitif yönlü bir ilişsinin bulunduğu düşünülmektedir.

$\mathrm{H}_{1}$ : Psikolojik sözleşmenin ilişkisel türünde algılanan ihlalin ( $\mathrm{H} 1 \mathrm{a}$ : gelişim olanakları boyutunda, $\mathrm{H} 1 \mathrm{~b}$ : otonomi ve kontrol boyutunda, H1c: iş özellikleri boyutunda), işten ayrılma niyeti üzerinde pozitif yönlü ve anlamlı bir etkisi vardır.

$\mathrm{H}_{2}$ : Psikolojik sözleşmenin işlemsel türünde algılanan ihlalin (H2a: faydalar boyutunda, H2b: çalışma koşulları boyutunda), işten ayrılma niyeti üzerinde pozitif yönlü ve anlamlı bir etkisi vardır.

Aselage ve Eisenberger (2003) psikolojik sözleşme ihlali algılayan çalışanların, örgüt tarafından mutluluğunun önemsenmediğini ve katkılarına değer verilmediğini düşüneceğini belirtmektedir. Rousseau (1989) da benzer şekilde psikolojik sözleşme ihlali sonucunda çalışanların yalnızca kendilerine verilen vaatlere ilişkin olumsuz duygular geliştirmeyeceğini, bununla birlikte örgütle aralarındaki ilişkinin derecesine dair daha genel bir duygunun da ortaya çıkacağını belirtmektedir. Dolayısıyla örgüt tarafından kendisine verilen vaatlerin yerine getirilmediğini düşünen çalışanlar, örgüt içerisinde değerli olmadıklarına inanmakta ve örgütsel destek algıları azalmaktadır.

Bu ilişki, ampirik araştırmalar kapsamında da ortaya konulmaktadır. Coyle-Shapiro ve Kessler (2000) tarafından gerçekleştirilen araştırma ile yöneticilerin vaat ettiği yükümlülükleri yerine getirmesinin, çalışanların algıladıkları destek, bağlılık ve vatandaşlık davranışları üzerinde olumlu bir etkiye sahip olduğu belirlenmiştir. Coyle-Shapiro ve Conway (2005) de benzer şekilde yerine getirilen vaatler sonucunda, çaIışanların örgüt tarafından kendilerine verilen destek algısında bir artış meydana geldiğini tespit etmiştir. Kiewitz vd. (2009) tarafından gerçekleştirilen çalışma ise, ilişkisel ve işlemsel sözleşmelerinde ihlal algılayan ve aynı zamanda örgüt politikalarına katılım derecesi düşük olan çalışanların daha az örgütsel destek algısına sahip olduğunu göstermektedir. Suazo (2009)'nın araştırması ile de algılanan psikolojik sözleşme ihlalinin, çalışanların örgütsel destek algısının güçlü bir belirleyici olduğunu ortaya konulmaktadır. Dolayısıyla, psikolojik sözleşme ihlal algısı ile algılanan örgütsel destek arasında negatif yönlü bir ilişkinin bulunduğu düşünülmektedir.

$\mathrm{H}_{3}$ : Psikolojik sözleşmenin ilişkisel türünde algılanan ihlalin (H3a: gelişim olanakları boyutunda, H3b: otonomi ve kontrol boyutunda, H3c: iş özellikleri boyutunda), algılanan örgütsel destek üzerinde negatif yönlü ve anlamlı bir etkisi vardır.

$\mathrm{H}_{4}$ : Psikolojik sözleşmenin işlemsel türünde algılanan ihlalin (H4a: faydalar boyutunda, H4b: çalışma koşulları boyutunda), algılanan örgütsel destek üzerinde negatif yönlü ve anlamlı bir etkisi vardır.

Oluşturulan hipotezler çerçevesinde belirtilen ilişkilerin bütünsel olarak gösterildiği araştırma modeli Şekil 1'de sunulmaktadır.

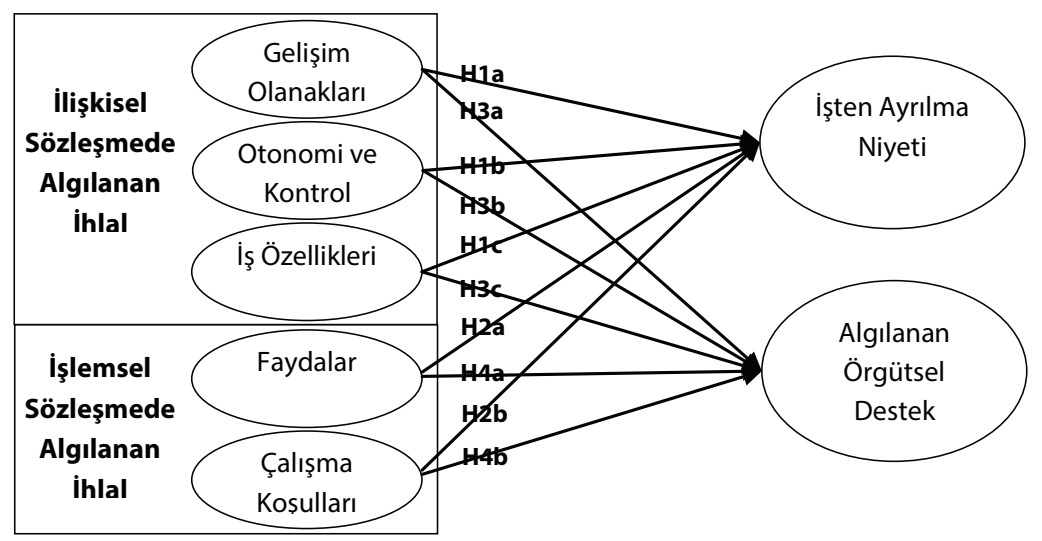

Şekil 1: Araştırma Modeli 


\section{METODOLOJi}

\subsection{Amaç ve Katkı}

Bu çalışma psikolojik sözleşme ihlal algısına odaklanmakta ve akademisyenler tarafından algılanan psikolojik sözleşme ihlalinin sonuçlarını belirlemeyi amaçlamaktadır. Spesifik olarak çalışmanın amacı ise, psikolojik sözleşmelerin iki türü olan ilişkisel ve işlemsel sözleşmelerde algılanan ihlalin, üniversitelerde görev yapan akademik personelin işten ayrılma niyeti ve algıladığı örgütsel destek üzerindeki etkisini ortaya koyabilmektir. Akademik personel ile üniversitesi arasındaki mübadele ilişkisinin yapısında meydana gelecek anlaşmazlıkların ve bu anlaşmazlıklar sonucu ortaya çıkabilecek olumsuz tepkilerin belirlenmesi amacını taşıyan bu çalışma ile, başarısını ve sunduğu hizmet kalitesini artırmak isteyen üniversitelere önemli katkılar sağlayabilmek hedeflenmektedir. Bununla birlikte bu tür bir çalışmanın, üniversite çalışanlarının eğitim ve akademik performansının artırılmasına katkı sağlayacağı düşünülmektedir.

\subsection{Evren ve Örneklem}

Çalışmanın evrenini, Türkiye'de bulunan devlet ve vakıf üniversitelerinin iktisadi ve idari bilimler, iktisat, işletme, siyasal bilgiler, ticari bilimler, yönetim bilimleri ve işletme ve yönetim bilimleri fakültelerinde görev yapan akademik personel oluşturmaktadır. Bu çerçevede belirtilen fakültelerde görevli profesör, doçent, yardımcı doçent, araştırma görevlisi, araştırma görevlisi doktor, öğretim görevlisi, öğretim görevlisi doktor, uzman ve okutman unvanlarına sahip tüm çalışanlar evren içerisinde yer almaktadır.

Yükseköğretim Kurulu (YÖK)'ndan ve üniversitelerin internet sayfalarından elde edilen bilgiler çerçevesinde Türkiye'de devlet ve vakıf üniversitelerinde görev yapan toplam akademik personel sayısının 80008500 kişi olduğu düşünülmektedir. Her bir üniversitenin internet sayfası aracılığıyla toplam akademik personelin 6681 tanesinin elektronik posta adreslerine ulaşılabilmiştir. Ana kütleden \%95 güvenilirlik sınırları içerisinde ve $\% 5^{\prime}$ lik bir hata payı dikkate alınarak en düşük örneklem büyüklüğü 367 kişi olarak hesaplanmıştır (Sekaran, 1992:253). Bu kapsamda evren içerisinden, geri dönüş oranları da hesaba katılarak basit tesadüfi örnekleme yöntemi ile seçilen 3500 kişiye anketler elektronik posta aracılığıyla gönderilmiştir. Posta kutularının dolu olması ve sunucudan kaynaklı hatalar gibi nedenlerden dolayı 379 kişiye anket formu ulaştırılamamıştır. Dolayısıyla 3121 kişinin anket formunu gördüğü düşünülmektedir. Cevaplayıcıların 641'inden geri dönüşs sağlanmıştır ve anketlerin geri dönüş oranı $\% 20,5$ olarak gerçekleşmiştir. Yapılan inceleme sonucunda 17 anketin uç değerlere sahip olduğu tespit edilmiş ve geçersiz sayılarak analiz dışında bırakılmıştır. Bununla birlikte 54 kişinin ise mevcut üniversitesinde veya meslek hayatında ilk senesinin içinde olduğu tespit edilmiştir. Gerçekleştirilen araştırmalar, bireyin psikolojik sözleşmesinin oluşum sürecinde ilk yılın sosyalizasyon aşaması olarak kabul edildiğini ve dolayısıyla daha tam olarak psikolojik sözleşmesi oluşmamış bireyler tarafından algılanan ihlallerin hatalar barındırabileceğini göstermektedir (Robinson, 1996; Rousseau, 1995). Dolayısıyla henüz sosyalizasyon aşamasını tamamlamadığı düşünülen 54 kişi de analiz dışında bırakılmıştır. Sonuç olarak toplam 71 anket analiz dışı bırakılmış ve analizler 570 anket üzerinden gerçekleştirilmiştir.

\subsection{Veri Toplama Yöntemi}

Çalışmada veri toplama amacıyla anket yöntemi kullanılmıştır. Anket formunun ilk bölümünde işlemsel ve ilişkisel psikolojik sözleşme çerçevesinde çalışanlara vaat edildiği düşünülen maddeler bulunmaktadır. Katılımcılardan bu maddelere ilişkin herhangi bir vaat algılayıp algılamadığını ve algılamış ise bu vaatlere ilişkin herhangi bir ihlal algılayıp algılamadığını belirtmeleri istenmektedir. İkinci bölümde işten ayrılma niyetinin ve algılanan örgütsel desteğin derecesini belirlemeye yönelik maddeler yer almaktadır. Anket formunun üçüncü bölümü ise çalışanların demografik özelliklerine ilişkin sorulardan oluşmaktadır.

\section{4. Ölçekler}

Çalışma kapsamında belirlenen hipotezlerin test edilmesi amacıyla, daha önce çeşitli çalışmalarda kullanılan ölçekler incelenmiş ve araştırma yapısına uygun olduğu düşünülen ölçekler anket formunda kullanılmıştır.

\subsubsection{Psikolojik Sözleşme İhlal Algısı Ölçeği}

Akademik personel tarafından algılanan psikolojik sözleşme ihlalinin boyutsal yapısını ve spesifik unsurlara ilişkin algılanan ihlalin derecesini belirleyebilmek amacıyla Kickul (2001), Kickul ve Lester (2001), Robinson ve Morrison (1995) ve Turnley ve Feldman (1999) tarafından gerçekleştirilen çalışmalarda kullanılan unsurlar çerçevesinde oluşturulan 26 maddelik ölçek kullanılmıştır. Ölçek çerçevesinde katılımcılara ücret, gelişim fırsatları, terfi olanakları gibi çeşitli unsuları kapsayan 26 maddelik bir liste sunulmuş ve üniversite tarafından vaat edildiğini düşündükleri, dolayısıyla üniversitenin yükümlülüğü olarak gördükleri unsurların ne derece yerine getirildiğini belirtmeleri istenmiştir. Belirtilen 26 maddenin 17 tanesi ilişkisel psikolojik sözleşmelere ve 9 tanesi ise işlemsel psikolojik sözleşmelere ilişkin unsurlardan oluşmaktadır. Bu çerçevede maddeler, " $1=$ Hiçbir Şekilde Yerine Getirilmedi", "2= Düşük Ölçüde Yerine Getirildi", "3= 
Orta Ölçüde Yerine Getirildi", "4= Büyük Ölçüde Yerine Getirildi" ve " $5=$ Tamamen Yerine Getirildi" şeklinde değişen cevaplara sahiptir. Daha sonra algılanan ihlalin büyüklüğünü belirleyebilmek için cevaplar ters çevrilmiştir. Bununla birlikte, herhangi bir unsura ilişkin vaat algılanmamış ve dolayısıyla üniversitenin belirtilen unsura ilişkin bir yükümlülüğünün olmadığı düşünülüyorsa, katılımcılardan, "Üniversitemin Böyle Bir Yükümlülüğü Yoktur" şıkkını seçmeleri istenmiştir. Böylece bireyin psikolojik sözleşmesi kapsamında yer almayan unsurlar analiz dışı bırakılmaktadır.

\subsection{2. İşten Ayrılma Niyeti Ölçeği}

Akademik personelin işinden ayrılma konusundaki tutumunu belirleyebilmek amacıyla Cammann vd. (1983) tarafından geliştirilen ve Michigan Örgütsel Değerlendirme Anketi içerisinde yer alan, işten ayrılma niyeti ölçeğinden yararlanılmıştır. Ölçek, 3 maddeden oluşmaktadır ve beşli likert tipinde uygulanmaktadır. Maddeler, " $1=$ Kesinlikle Katılmıyorum" ile " $5=$ Kesinlikle Katılıyorum" arasında değişen cevaplar barındırmaktadır. Bu çerçevede yüksek skorlar, işten ayrılma niyetinin yüksek olduğuna işaret etmektedir. Ölçekte olumsuz tutum ifadesi bulunmamaktadır.

\subsubsection{Algılanan Örgütsel Destek Ölçeği}

Akademik personelin algıladığı örgütsel desteğin derecesini belirleyebilmek amacılla Eisenberger vd. (1986) tarafından geliştirilen 36 ifadelik ölçeğin, Eisenberger vd. (1997) tarafından kısaltılarak ve geçerlilik analizi gerçekleştirilerek oluşturulmuş hali kullanımıştır. Toplam 8 maddeden oluşan ölçekte cevaplar beşli likert ölçeğiyle alınmıştır. Maddeler, " $1=$ Kesinlikle Katılmıyorum" ile " $5=$ Kesinlikle Katılıyorum" arasında değişen cevaplara sahiptir. Yüksek skorlar, yüksek derecede örgütsel destek algısını ifade etmektedir. Ölçekte, olumsuz tutum ifadesi şeklinde yer alan iki ifade bulunmaktadır. Bu ifadeler analize ters çevrilerek katılmıştır.

\subsection{Analiz Yöntemi}

Araştırma çerçevesinde kullanılan ölçeklere ilişkin yapı geçerliliği faktör analizi ile test edilmiştir. Psikolojik sözleşme unsurlarında algılanan ihlalin derecesini ölçmek için kullanılan içerik ölçeği, literatürde yer alan çeşitli çalışmalarda kullanılan ölçeklerden yararlanılarak oluşturulmuştur (Kickul, 2001; Kickul ve Lester, 2001; Robinson ve Morrison, 1995; Turnley ve Feldman, 1999). Dolayısıyla oluşturulan ölçeğin yapı geçerliliğini test edebilmek için ölçek maddelerine açıklayıcı faktör analizi uygulanmıştır. Çalışmada kullanılan diğer ölçekler ise (işten ayrılma niyeti ölçeği ve algılanan örgütsel destek ölçeği), literatürde birçok çalışma tarafından kullanılmış ve bu çalışmalar kapsamında ölçeklerin tek faktörlü yapıları doğrulanmıştır.
Dolayısıyla bu ölçeklerin yapı geçerliliklerini test edebilmek amacıyla doğrulayıc faktör analizinden yararlanılmıştır. Açıklayıcı ve doğrulayıcı faktör analizlerine ek olarak tüm ölçeklerin güvenilirlik analizleri de gerçekleştirilmiştir. Güvenilirlik analizi kapsamında ölçeklerin içsel tutarlılığını belirleyebilmek için Cronbach Alfa (a) istatistiğinden yararlanılmıştır. Çalışmada yer alan hipotezler ise hiyerarşik regresyon analizi ile test edilmiştir. Çalışma kapsamında gerçekleştirilen açıklayıcı faktör analizi, güvenilirlik analizleri ve hiyerarşik regresyon analizi için SPSS 19 programından, doğrulayıcı faktör analizi için ise AMOS 19 programından faydalanılmıştır.

\section{BULGULAR}

Bulgular kapsamında, çalışmanın örnekleminin demografik özelliklerine ilişkin bulgulara, geçerlilik ve güvenilirlik analizleri sonuçlarına, tanımlayıcı istatistiklere ilişkin değerlendirmelere ve amaç çerçevesinde oluşturulan hipotezlere ilişkin analiz sonuçlarına yer verilmektedir.

\subsection{Demografik Bilgiler}

Çalışmaya katılan akademik personelin üniversite, cinsiyet, yaş, medeni durum, unvan, meslekte çalışma yılı ve üniversitede çalışma yılı değişkenlerine göre demografik özelliklerine göre dağılımı Tablo 1’de gösterilmektedir.

Tablo 1: Katılımcıların Demografik Dağılımı

\begin{tabular}{|c|c|c|c|c|c|}
\hline Medeni Durum & $\mathrm{N}$ & $\%$ & Cinsiyet & $\mathrm{N}$ & $\%$ \\
\hline Evli & 346 & 60,7 & Kadın & 246 & 43,2 \\
\hline Bekar & 224 & 39,3 & Erkek & 324 & 56,8 \\
\hline Yaş & & & Üniversite & & \\
\hline $20-30$ arası & 177 & 31,1 & Vakıf & 123 & 21,6 \\
\hline $31-40$ arası & 246 & 43,2 & Devlet & 447 & 78,4 \\
\hline 41-50 arası & 103 & 18,1 & Unvan & & \\
\hline 51 ve üstü & 44 & 7,6 & Profesör Dr & 62 & 10,8 \\
\hline \multicolumn{3}{|c|}{ Meslekte Çalışma Süresi } & Doçent Dr & 83 & 14,6 \\
\hline $2-5$ yıl & 179 & 31,4 & $\begin{array}{l}\text { Yardımcı } \\
\text { Doçent Dr }\end{array}$ & 154 & 27,0 \\
\hline 6-10 yıl & 167 & 29,3 & $\begin{array}{l}\text { Öğretim } \\
\text { Görevlisi }\end{array}$ & 20 & 3,5 \\
\hline 10 yıldan fazla & 224 & 39,3 & $\begin{array}{l}\text { Öğretim } \\
\text { Görevlisi Dr }\end{array}$ & 16 & 2,8 \\
\hline \multicolumn{3}{|c|}{ Üniversitede Çalışma Süresi } & $\begin{array}{l}\text { Araştırma } \\
\text { Görevlisi }\end{array}$ & 189 & 33,2 \\
\hline 2-5 yıl & 243 & 42,6 & $\begin{array}{l}\text { Araştırma } \\
\text { Görevlisi Dr }\end{array}$ & 44 & 7,7 \\
\hline 6-10 yıl & 180 & 31,6 & Uzman & 1 & 0,2 \\
\hline 10 yıldan fazla & 147 & 25,8 & Okutman & 1 & 0,2 \\
\hline
\end{tabular}


Tablo 1'den elde edilen bulgular kapsamında, katılımcıların büyük çoğunluğunun devlet üniversitelerinde görev yaptığı $(\% 78,4)$ ve $20-40$ yaş arasında olduğu $(\% 74,3)$ belirlenmiştir. Bununla birlikte çalışmaya katılan akademisyenlerin çoğunluğunun erkek $(\% 56,8)$ ve evli olduğu $(\% 60,7)$ görülmektedir. Unvanlara göre dağılımlara bakıldığında ise, araştırma görevlisi $(\% 33,2)$ ve yardımcı doçent doktor $(\% 27)$ unvanına sahip akademisyenlerin sayısının daha fazla olduğu belirlenmiştir. Ayrıca çalışmaya katılan akademisyenlerin çoğunluğunun 10 yıldan fazla süredir akademisyenlik yaptığı $(\% 39,3)$, fakat 2-5 yıl arasında bir süredir mevcut üniversitesinde çalışmakta olduğu $(\% 42,6)$ görülmektedir.

\subsection{Geçerlilik ve Güvenilirlik Analizleri}

Psikolojik sözleşme ihlalinin derecesini belirleyebilmek amacıyla kullanılan ölçeğinin çeşitli araştırmalarda kullanılan unsurlar çerçevesinde oluşturulması nedeniyle (Kickul, 2001; Kickul ve Lester, 2001; Robinson ve Morrison, 1995; Turnley ve Feldman, 1999) ve boyutsal yapısını ortaya koyabilmek amacıyla, ölçek kapsamında yer alan 26 maddeye açıklayıcı faktör analizi uygulanmıştır. Gerçekleştirilen açıklayıc faktör analizi sonucunda ölçekte yer alan "terfi ve meslekte ilerleme imkanı sunulması" şeklindeki ifadenin faktör yükünün 0,50'nin altında olduğu gözlenmiştir. Bununla birlikte "ihtiyaç duyduğum kaynağın sağlanması (eğitim bursu, araştırma bursu, staj bursu, kongre, seminer katilim desteği, araştırmalara maddi destek gibi)" şeklindeki ifadenin ise iki farklı faktör altında 0,50'nin üzerinde mutlak değer ağırlığına sahip olduğu tespit edilmiştir. Dolayısıyla bu iki ifade analiz dışında bırakılarak faktör analizi tekrarlanmıştır (Brown, 2006). Faktör yapısına uyum sağlamayan iki ifadenin analiz dışında bırakılması ile gerçekleştirilen faktör analizi sonuçları Tablo 2'de gösterilmektedir.

Tablo 2: Psikolojik Sözleşme İhlal Algısı Ölçeğine İlişkin Açıklayıcı Faktör Analizi Sonuçları

\begin{tabular}{|c|c|c|c|c|c|c|}
\hline & ÖLÇEK MADDELERI & 1 & 2 & 3 & 4 & 5 \\
\hline \multirow{6}{*}{ 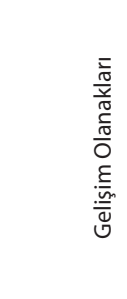 } & 1.Yurtdışına eğitim, kongre, araştırma vb. amaçlarla çıkabilme fırsatı verilmesi & ,801 & 047 & ,238 & , 143 & , 143 \\
\hline & 2.Akademik faaliyetlerime ilişkin destek sağlanması & ,763 & ,282 & 175 & 144 & , 108 \\
\hline & $\begin{array}{l}\text { 3.Üniversite dışında da uzmanlık alanımla ilgili çalışma imkanı } \\
\text { verilmesi(danışmanlık, eğitim, seminer verme gibi...) }\end{array}$ & ,673 & ,206 & 311 & 234 & 112 \\
\hline & 4.Bireysel gelişim imkanı verilmesi & 640 &, 452 & 227 & 094 & 213 \\
\hline & 5.Başarılarımın üniversite tarafından ödüllendirilmesi & ,583 & ,436 & 140 & 100 & ,223 \\
\hline & 6Yeteneklerimi geliştirebilme fırsatı sunulması & ,567 & ,466 & ,222 & 071 & 281 \\
\hline & 7.Gerçekleştirdiğim işe ilişkin geri bildirim sağlanması & 171 & ,752 & 137 & 116 & 137 \\
\hline రิ & 8.Beni etkileyen kararlarda söz sahibi olabilme & ,270 & ,714 & ,271 & 179 & 052 \\
\hline$\stackrel{\Delta}{=}$ & 9.Terfi ve atamalarda objektif kriterlerin uygulanması & 155 & ,678 & ,288 & , 167 & 084 \\
\hline$\stackrel{\bar{o}}{c}$ & 10.|̇simde kontrol ve otonomi sahibi olabilme & ,266 & ,573 & ,419 & 051 & , 198 \\
\hline ठั & 11.Yaratıcı olabilme özgürlüğü verilmesi & ,449 & ,561 & ,286 & 036 & ,216 \\
\hline & 12.Gereksiz ve aşırı iş yükümün olmaması & ,048 & 252 & ,717 & 180 & 035 \\
\hline$\underline{\underline{L}}$ & 13.Kesintisiz iş güvencesi sağlanması & 194 & 122 & ,711 &,- 001 & 120 \\
\hline$\overline{\bar{g}}$ & 14.Esnek çalışma saatlerimin olması & 325 & 135 & 700 &,- 076 & 143 \\
\hline$\underline{u}$ & 15.Adil olarak ayarlanmış ve dağıtılmış ders yükümün olması & ,263 & ,302 & ,648 &,- 025 & ,208 \\
\hline & 16.Açık ve iyi şekilde tanımlanmış sorumluluklarımın olması & 204 & ,369 & ,578 & 174 & 116 \\
\hline & 17.Lojman veya kira yardımı verilmesi &,- 012 & 025 & 100 & ,821 & 199 \\
\hline$\frac{\pi}{\frac{\pi}{\pi}}$ & 18.Eğitim ve gelişim için bireysel ödenek sağlanması & ,231 & 168 &,- 051 & ,794 & 095 \\
\hline స్ & 19.Yeterli maddi kazanç sağlama & 133 & ,215 & 055 & ,722 & 176 \\
\hline & 20. Iyileştirilmiş sağlık hizmetleri sunulması & 100 & 029 & ,060 & ,712 & ,218 \\
\hline$\frac{\overline{\bar{\sigma}}}{\overline{\bar{J}}}$ & $\begin{array}{l}\text { 21.Teknolojik altyapının iyileştirilmesi (bilgisayarlar, elektronik aygıtlar, veritabanları } \\
\text { gibi) }\end{array}$ & 152 & 090 & 169 & 201 & ,810 \\
\hline$\stackrel{0}{\stackrel{0}{a}}$ & 22.Fiziksel altyapının iyileştirilmesi (sınıflar, laboratuarlar, ofisler gibi) & 127 & 117 & 079 & ,294 & ,798 \\
\hline$\underline{\underline{E}}$ & 23.Eğitim ve araştırma sırasında ihtiyaç duyduğum araç gerecin sağlanması & ,307 & 178 & 092 & 417 & ,604 \\
\hline$\tilde{u}$ & 24.Güvenli iş ortamı sunulması & 209 & 275 & ,299 & 178 & ,598 \\
\hline Özdeğerler & & 9,732 & 2,610 & 1,276 & 1,188 & 1,001 \\
\hline Varyansı Açı & anı (\%) & 40,551 & 10,873 & 5,318 & 4,952 & 3,955 \\
\hline Kümülatif Va & çıklama Oranı (\%) & 40,551 & 51,424 & 56,741 & 61,693 & 65,648 \\
\hline KMO Uygun & tü $=0,939$ & & & & & \\
\hline Barlett Küres & ti $\quad x 2=4514,299 \quad s d=276$ & $p=, 00$ & & & & \\
\hline
\end{tabular}


Gerçekleştirilen açıklayıc faktör analizi sonucunda varyansı açıklama yüzdesi birden büyük olan beş faktör belirlenmiştir ve bu beş faktörün toplam değişkenliğin \%65,648'ini açıklama yeteneğine sahip olduğu tespit edilmiştir. Bu çerçevede birinci faktör (6 madde), bireye üniversitesi tarafından ilişkisel sözleşmesi kapsamında vaat edildiği düşünülen akademik ve idari gelişimine yönelik unsurları içermektedir. Dolayısıyla ilk faktör gelişim olanakları olarak isimlendirilmektedir. İinci faktör (5 madde) içerisinde bireyin ilişkisel sözleşmesi kapsamında, gerçekleştirdiği işe ilişkin sahip olduğu otonomi ve kontrol derecesiyle ilgili unsurlar bulunmakta ve dolayısıyla faktör otonomi ve kontrol şeklinde isimlendirilmektedir. Üçüncü faktör ( 5 madde) altında bireyin gerçekleştirdiği işin genel özelliklerine ilişkin, ilişkisel sözleşmesi kapsamında vaat edildiği düşünülen unsurlar yer almaktadır ve bu faktör iş özellikleri olarak isimlendirilmektedir. Dördüncü faktör (4 madde) bireyin işlemsel sözleşmesi çerçevesinde üniversitesi tarafından sağlanan faydalara ve olanaklara ilişkin unsurları kapsamaktadır. Dördüncü faktör faydalar şeklinde adlandırılmaktadır. Beşinci faktör (4 madde) içerisinde ise bireyin işlemsel sözleşmesi çerçevesinde üniversitesi tarafından sunulan çalışma şartlarına ilişkin unsurlar bulunmaktadır. Dolayısıyla beşinci faktör çalışma koşulları olarak adlandırılmaktadır.

Bununla birlikte çalışmada kullanılan işten ayrılma niyeti ölçeği ve algılanan örgütsel destek ölçeği ise, literatürde birçok çalışma tarafından kullanılmış ve bu çalışmalar kapsamında ölçeklerin tek faktörlü yapıları doğrulanmıştır. Dolayısıyla bu ölçeklerin yapı geçerliliklerini test edebilmek amacıyla doğrulayıcı faktör analizinden yararlanılmıştır. Doğrulayıcı faktör analizinde genel model uyumu, ki kare uyum testi (x2/sd), uyum iyiliği indeksi (GFI), düzeltilmiş uyum iyiliği indeksi (AGFI), normlandırılmış uyum indeksi (NFI), Tucker-Lewis indeksi (TLI), karşılaştırmalı uyum indeksi (CFI) ve yaklaşık hataların ortalama karekökü (RMSEA) aracilığıyla test edilmiştir.

Gerçekleştirilen doğrulayıcı faktör analizi sonucunda algılanan örgütsel destek ölçeği içerisinde yer alan "Fırsat bulduğu takdirde üniversitemin iyi niyetimi kötüye kullanacağını düşünüyorum" ve "Üniversitemin beni umursamadığını düşünüyorum" şeklindeki ifadelerin faktör yapısını ve uyum iyiliğine ilişkin istatistikleri olumsuz olarak etkilediği gözlenmiştir. Dolayısıyla bu iki ifade analiz dışı bırakılarak analiz tekrarlanmıştır. Belirtilen iki maddenin analiz dışında bırakılması ve düzeltme indeksleri sonucunda uyum iyiliğine ilişkin kriterler incelendiğinde bazı değerlerin kabul edilebilir sınırlar içerisinde olmasına rağmen $(x 2 / s d=3,848, R M S E A=0,071)$, diğer kriterlerin iyi uyum sağladığı görülmektedir (GFI=0,965, AGFI=0,935, NFI=0,980, TLI=0,978, CFI=0,985). Dolayısıyla uyum iyiliği kriterleri çerçevesinde modeldeki ilişkilerin örneklem verisi ile yüksek derecede tutarlı olduğu söylenebilmektedir.

Doğrulayıcı faktör analizi sonucunda işten ayrılma niyeti ölçeğine ve algılanan örgütsel destek ölçeğine ilişkin standardize edilmemiş ve standardize edilmiş değerler, standart hatalar, t-değerleri ve karesi alınmış çoklu korelasyonlar ( $\left.\mathrm{R}^{2}\right)$ Tablo 3'de gösterilmektedir.

Tablo 3: Iş̧ten Ayrılma Niyeti ve Algılanan Örgütsel Destek Ölçeğine İlişkin Doğrulayıcı Faktör Analizi Sonuçları

\begin{tabular}{|c|c|c|c|c|c|}
\hline Maddeler & $\begin{array}{l}\text { Standardize } \\
\text { Edilmemiş } \\
\text { Değerler }\end{array}$ & $\begin{array}{l}\text { Standardize } \\
\text { Edilmiş } \\
\text { Değerler }\end{array}$ & $\begin{array}{l}\text { Standart } \\
\text { Hatalar }\end{array}$ & t-değeri & $\mathrm{R}^{2}$ \\
\hline \multicolumn{6}{|l|}{ İşten Ayrılma Niyeti Ölçeği } \\
\hline $\begin{array}{l}\text { 1.Önümüzdeki yıl muhtemelen farklı bir üniversitede çalışmak için iş } \\
\text { arıyor olacağım. }\end{array}$ & 1,030 & $0,971^{*}$ & 0,025 & 40,469 & 0,943 \\
\hline 2.Önümüzdeki yıl kesinlikle farklı bir üniversitede çalışıyor olacağım. & 0,970 & $0,948^{*}$ & 0,025 & 38,242 & 0,899 \\
\hline 3.Çalıştığım üniversiteden ayrılmayı sık sık düşünüyorum. & 1,000 & $0,892^{*}$ & - & - & 0,796 \\
\hline \multicolumn{6}{|l|}{ Algılanan Örgütsel Destek Ölçeği } \\
\hline 1.Üniversitem, fikirlerimi önemsemektedir & 0,933 & $0,740^{*}$ & 0,050 & 18,743 & 0,548 \\
\hline 2.Üniversitem, mutluluğuma gerçekten önem vermektedir. & 1,174 & $0,890^{*}$ & 0,050 & 23,603 & 0,792 \\
\hline 3.Üniversitem, amaçlarıma ve değerlerime saygı göstermektedir. & 1,169 & $0,878^{*}$ & 0,050 & 23,221 & 0,771 \\
\hline $\begin{array}{l}\text { 4.Herhangi bir sorunla karşı karşıya kaldığımda üniversitem her zaman } \\
\text { için yardıma hazırdır. }\end{array}$ & 1,073 & $0,835^{*}$ & 0,049 & 21,804 & 0,698 \\
\hline $\begin{array}{l}\text { 5.Üniversitemin, istemeden yaptığım bir hatayı bağışlayabileceğini } \\
\text { düşünüyorum. }\end{array}$ & 0,979 & $0,760^{*}$ & 0,044 & 22,026 & 0,577 \\
\hline $\begin{array}{l}\text { 6.Özel (kişisel) bir iyilik istemem durumunda üniversitemin bana } \\
\text { yardım etmeye hazır olduğunu düşünüyorum. }\end{array}$ & 1,000 & $0,778^{*}$ & - & - & 0,606 \\
\hline
\end{tabular}

( Not: $\left.{ }^{*} p<0,01\right)$ 
Tablo 3'de sunulan doğrulayıcı faktör analizi sonuçları kapsamında, işten ayrılma niyeti ölçeği için faktör yüklerinin 0,892 ile 0,971 arasında olduğu ve algılanan örgütsel destek ölçeği için faktör yüklerinin 0,740 ile 0,890 arasında tespit edilmiştir. Bununla birlikte analiz sonucunda en düşük t-değerinin 18,743 olduğu, dolayısıyla faktör yüklerinin 0,01 önemlilik seviyesinde anlamlı olduğu belirlenmiştir. Sonuç olarak, gerçekleştirilen doğrulayıc faktör analizi ile işten ayrılma niyeti ölçeğine ilişkin üç maddelik, tek faktörlük

Tablo 4: Psikolojik Sözleşme İhlal Algısı Ölçeğine İlişkin Güvenilirlik Değerleri

\begin{tabular}{|l|c|c|}
\hline Ölçek / Boyut & Madde Sayısı & Güvenilirlik Değeri (a) \\
\hline Psikolojik Sözleşme İhlal Algısı Ölçeği & 24 & 0,926 \\
\hline Gelişim Olanakları Boyutu (illişkisel) & 6 & 0,899 \\
\hline Otonomi ve Kontrol Boyutu (Illişkisel) & 5 & 0,854 \\
\hline İş Özellikleri Boyutu (ilişkisel) & 5 & 0,808 \\
\hline Faydalar Boyutu (İşlemsel) & 4 & 0,816 \\
\hline Çalışma Koşulları Boyutu (İşlemsel) & 4 & 0,837 \\
\hline İşten Ayrılma Niyeti Ölçeği & 3 & 0,954 \\
\hline Algılanan Örgütsel Destek Ölçeği & 6 & 0,922 \\
\hline
\end{tabular}

Tablo 4 incelendiğinde, tüm ölçeklere ve alt boyutlara ilișkin elde edilen güvenilirlik değerlerinin 0,70 'in üzerinde olduğu belirlenmiștir (Nunnally ve Bernstein, 1994:265). Bu sonuçlar çerçevesinde psikolojik sözleşme ihlal algısı, işten ayrılma niyeti ve algılanan örgütsel destek ölçeklerinin yapısal olarak geçerli ve güvenilir ölçekler olduğu görülmektedir.

\subsection{Tanımlayıcı İstatistikler}

yapı ve algılanan örgütsel destek ölçeğine ilişkin altı maddelik, tek faktörlük yapı doğrulanmıştır.

Geçerlilik analizlerinin ardından güvenilirlik analizleri gerçekleştirilmiştir. Güvenilirlik değerleri, ölçeğin belirlenen her bir alt boyutuna ve ölçekte yer alan ifadelerin tamamına ilişkin hesaplanan Cronbach Alfa (a) istatistiğinin hesaplanması ile belirlenmiştir. Ölçeklere ilişkin elde edilen güvenilirlik değerleri Tablo 4'de gösterilmektedir.

Tanımlayıcı istatistikler kapsamında, ilişkisel psikolojik sözleşmenin üç boyutunu oluşturan gelişim olanakları, otonomi ve kontrol ve iş özellikleri boyutlarında algılanan ihlale, işlemsel psikolojik sözleşmenin iki boyutunu oluşturan faydalar ve çalışma koşulları boyutlarında algılanan ihlale, işten ayrılma niyetine ve algılanan örgütsel desteğe ilişkin ortalama, standart sapma ve korelasyon değerleri incelenmektedir. Bulgular Tablo 5'de sunulmaktadır.

Tablo 5: Ortalama, Standart Sapma ve Korelasyon Değerleri

\begin{tabular}{|c|c|c|c|c|c|c|c|c|c|c|}
\hline \multicolumn{2}{|c|}{ Değişken } & $\bar{X}$ & SS & 1 & 2 & 3 & 4 & 5 & 6 & 7 \\
\hline 1 & Gelişim Olanakları & 3,167 & 0,977 & - & & & & & & \\
\hline 2 & Otonomi ve Kontrol & 3,153 & 0,900 & $0,703^{*}$ & - & & & & & \\
\hline 3 & İş Özellikleri & 3,090 & 0,918 & $0,619 *$ & $0,657^{*}$ & - & & & & \\
\hline 4 & Faydalar & 3,173 & 1,041 & $0,401^{*}$ & $0,341^{*}$ & $0,246^{*}$ & - & & & \\
\hline 5 & Çalışma Koşulları & 2,599 & 0,923 & $0,553^{*}$ & $0,493^{*}$ & $0,458^{*}$ & $0,537^{*}$ & - & & \\
\hline 6 & İşten Ayrılma Niyeti & 2,395 & 1,260 & $0,536^{*}$ & $0,525^{*}$ & $0,510^{*}$ & $0,210^{*}$ & $0,375^{*}$ & - & \\
\hline 7 & Algılanan Örgütsel Destek & 2,947 & 0,969 & $-0,563^{*}$ & $-0,602^{*}$ & $-0,507^{*}$ & $-0,350 *$ & $-0,429 *$ & $-0,626^{*}$ & - \\
\hline
\end{tabular}

Tablo 5 incelendiğinde çalışma kapsamında kullanılan tüm değişkenler arasındaki karşılıklı ilişkilerin anlamlı $(p<0,01)$ ve beklenen yönde olduğu görülmektedir. Bu nedenle değişkenler arasında önemli etkiler öngörülebilmektedir.

\subsection{Hipotez Testleri}

Illişkisel ve işlemsel psikolojik sözleşme ihlalinin alt boyutlarının işten ayrılma niyeti ve algılanan örgütsel destek üzerindeki etkisi hiyerarşik regresyon analizi ile incelenmiştir. Analizin ilk aşamasında kontrol değişkenlerinin (cinsiyet, yaş, medeni durum, unvan, üniversiten, meslekte çalışma süresi, üniversitede çalışma süresi) işten ayrılma niyeti ve algılanan örgütsel destek üzerindeki etkileri araştırılmıştır. İkinci aşamada ise modele bağımsız değişkenler (gelişim olanakları, otonomi ve kontrol, iş özellikleri, faydalar, çalışma koşulları) dahil edilmiştir. Hiyerarşik regresyon analizi sonuçları Tablo 6`da sunulmaktadır. 
Çalışmanın ilk iki hipotezi kapsamında ilişkisel ve işlemsel psikolojik sözleşmenin boyutlarında algılanan ihlalin, işten ayrılma niyeti üzerindeki etkisi araştırılmaktadır. Tablo 6'da yer alan analiz sonuçları incelendiğinde, ilişkisel psikolojik sözleşmenin gelişim olanakları boyutunda ( $\mathrm{H} 1 \mathrm{a}: \beta=0,249, \mathrm{p}<0,01)$, otonomi ve kontrol boyutunda $(H 1 b: \beta=0,179, p<0,05)$ ve iş özellikleri boyutunda ( $H 1 c: \beta=0,217, p<0,01)$ algılanan ihlalin, işten ayrılma niyeti üzerinde pozitif yönlü ve anlamlı bir etkisinin bulunduğu görülmektedir. Dolayısıyla, $\mathrm{H} 1$ hipotezi kabul edilmiştir. Buna karşılık işlemsel psikolojik sözleşmenin faydalar boyutunda ( $H 2 a: \beta=-0,048, p>0,05)$ ve çalışma koşulları boyutunda ( $\mathrm{H} 2 \mathrm{~b}: \beta=0,076, p>0,05)$ algılanan ihlalin, işten ayrılma niyeti üzerindeki etkisinin anlamsız olduğu belirlenmiştir. Dolayısıyla, $\mathrm{H} 2$ hipotezi reddedilmiştir

Tablo 6: Hiyerarşik Regresyon Analizi Sonuçları

\begin{tabular}{|c|c|c|c|c|}
\hline & \multicolumn{2}{|c|}{ İşten Ayrılma Niyeti } & \multicolumn{2}{|c|}{$\begin{array}{l}\text { Algılanan Örgütsel } \\
\text { Destek }\end{array}$} \\
\hline & 1. aşama & 2. aşama & 1. aşama & 2. aşama \\
\hline & $\beta$ & $\beta$ & $\beta$ & $\beta$ \\
\hline \multicolumn{5}{|l|}{$\begin{array}{l}\text { Kontrol } \\
\text { Değişkenleri }\end{array}$} \\
\hline Cinsiyet & 0,026 & 0,054 & 0,030 & 0,008 \\
\hline Yaş & $-0,046$ & 0,048 & 0,054 & $-0,036$ \\
\hline Medeni Durum & 0,027 & $-0,006$ & $-0,019$ & 0,026 \\
\hline Unvan & $0,234^{* *}$ & 0,083 & $-0,304^{*}$ & $-0,131^{* *}$ \\
\hline Üniversite & 0,006 & $-0,010$ & $-0,044$ & 0,009 \\
\hline $\begin{array}{l}\text { Meslekte } \\
\text { Çalışma Süresi }\end{array}$ & 0,050 & 0,011 & $-0,053$ & $-0,001$ \\
\hline $\begin{array}{l}\text { Üniversitede } \\
\text { Çalışma Süresi }\end{array}$ & 0,061 & 0,017 & $-0,142^{* *}$ & $-0,084$ \\
\hline \multicolumn{5}{|l|}{$\begin{array}{l}\text { Bağımsız } \\
\text { Değişkenler }\end{array}$} \\
\hline $\begin{array}{l}\text { Gelişim } \\
\text { Olanakları }\end{array}$ & & $0,249^{*}$ & & $-0,186^{*}$ \\
\hline $\begin{array}{l}\text { Otonomi ve } \\
\text { Kontrol }\end{array}$ & & $0,179^{* *}$ & & $-0,306^{*}$ \\
\hline İş Özellikleri & & $0,217^{*}$ & & $-0,127^{* *}$ \\
\hline Faydalar & & $-0,048$ & & $-0,097 * *$ \\
\hline $\begin{array}{l}\text { Çalışma } \\
\text { Koşulları }\end{array}$ & & 0,076 & & $-0,057$ \\
\hline F Değeri & $4,283^{*}$ & $26,581^{*}$ & $7,504^{*}$ & $19,369^{*}$ \\
\hline $\mathrm{R}^{2}$ & 0,051 & 0,364 & 0,085 & 0,434 \\
\hline Düzeltilmiş $\mathrm{R}^{2}$ & 0,039 & 0,350 & 0,074 & 0,422 \\
\hline$\Delta \mathrm{R}^{2}$ & & $0,313^{*}$ & & $0,349^{*}$ \\
\hline
\end{tabular}

( Not: ${ }^{*} p<0,01 ;{ }^{* *} p<0,05$ )

Üçüncü ve dördüncü hipotezler ile ilişkisel ve işlemsel psikolojik sözleşmenin boyutlarında algılanan ihlalin, algılanan örgütsel destek üzerindeki etkisi belirlenmeye çalışıımaktadır. Analiz sonuçlarına göre ilişkisel psikolojik sözleşmenin gelişim olanakları boyutunda ( $\mathrm{H} 3 \mathrm{a}: \beta=-0,186, p<0,01$ ), otonomi ve kontrol boyutunda ( $\mathrm{H} 3 \mathrm{~b}: \beta=-0,306, p<0,01)$ ve iş özellikleri boyutunda ( $\mathrm{H} 3 \mathrm{c}: \beta=-0,127, p<0,05)$ algılanan ihlalin, işten ayrılma niyeti üzerinde negatif yönlü ve anlamlı bir etkisinin bulunduğu tespit edilmiştir. Dolayısıyla, H3 hipotezi kabul edilmiştir. Bununla birlikte, işlemsel psikolojik sözleşmenin faydalar boyutunda $(\mathrm{H} 4 \mathrm{a}: \beta=-$ $0,097, p<0,05)$ algılanan ihlalin, işten ayrılma niyeti üzerinde negatif yönlü ve anlamlı bir etkisinin bulunduğu, fakat işlemsel psikolojik sözleşmenin çalışma koşulları boyutunda ( $\mathrm{H} 4 \mathrm{~b}: \beta=-0,057, \mathrm{p}>0,05)$ algılanan inlalin, işten ayrılma niyeti üzerindeki etkisinin anlamsız olduğu belirlenmiştir. Dolayısıyla, H4 hipotezi kısmen kabul edilmiştir.

\section{SONUÇ}

Çalışma kapsamında psikolojik sözleşme ihlal algısı, işten ayrılma niyeti ve algılanan örgütsel destek arasındaki ilişkiler araştırılmıştır. Bu çerçevede çalışmanın amacl, psikolojik sözleşmenin iki türü olan ilişkisel ve işlemsel sözleşmelerde algılanan ihlalin, işten ayrılma niyeti ve algıladığı örgütsel destek üzerindeki etkisini belirleyebilmektir.

Belirtilen amaç çerçevesinde çalışma, Türkiye'deki üniversitelerde görev yapan akademik personel üzerinde gerçekleştirilmiştir. Çalışma çerçevesinde kullanılan veri devlet ve vakıf üniversitelerinde görevli 570 akademik personelden elde edilmiştir. Dolayısıyla çalışma, akademik personelin istihdam ilişkisini sürdürdüğü üniversite ile arasındaki karşlıklılık ilişkisine odaklanmakta, karşılıkııık ilişkisinin yapısında meydana gelecek anlaşmazlıkların ve bu anlaşmazlıklar sonucu ortaya çıkabilecek olumsuz tepkilerin belirlenmesi amacını taşımaktadır. Bu yönüyle çalışmanın, eğitim kalitesini artırmak ve başarısını yükseltmek isteyen yükseköğretim kurumlarının akademik personel ile olan ilişkilerini düzenleyebilmesi açısından önem arz ettiği düşünülmektedir.

Çalışmada, oluşturulan hipotezler hiyerarşik regresyon analizi ile test edilmiştir. Verilerin analizi sonucunda elde edilen bulgular değerlendirildiğinde, ilk olarak, psikolojik sözleşmenin ilişkisel türü içerisinde yer alan unsurların akademik personelin işinden ayrılma niyeti üzerinde anlamlı etkiye sahip olduğu tespit edilmiştir. Psikolojik sözleşmenin işlemsel türü içerisinde yer alan unsurların ise işten ayrılma niyeti üzerinde anlamlı bir etkiye sahip olmadığı belirlenmiştir. Dolayısıyla akademik personelin mevcut üniversitesinden ayrılma isteğindeki artışta, psikolojik sözleşmesi kapsamındaki ekonomik veya maddi faktörlerde algıladığı ihlalden çok duygusal veya manevi faktörlerde algıladığı ihlalin etkili olduğu söylenebilir. 
Akademik personel için önemli olan, psikolojik sözleşmesi çerçevesinde üniversitenin yükümlülüğü olarak gördüğü ilişkisel unsurların (bireye işine ilişkin otonomi verilmesi, kendisini etkileyen kararlara ilişkin söz sahibi olabilmesi, bireysel gelişim olanağı sağlanması, başarılarının örgüt tarafından farkına varılıp ödüllendirilmesi, esnek çalışma saatlerinin olması, iş güvencesi verilmesi gibi) yerine getirilmesidir. Bu bulgunun, literatürde aynı ilişkiyi araştıran çalışmalarla uyumlu olduğu görülmektedir (Zhang vd., 2010; Zhao vd., 2007). Aynı zamanda bu bulgu, istihdam ilişkisi kapsamında bireyler tarafından sahip olunan psikolojik sözleşmelerde, ilişkisel unsurların daha önemli hale geldiği şeklinde oluşturulan kuramsal açıklamalarla da örtüşsmektedir (Anderson ve Schalk, 1998; Millward ve Hopkins, 1998; Shore ve Tetrick, 1994).

Bulgular kapsamında ikinci olarak ise, psikolojik sözleşmenin ilişkisel unsurlarında algılanan ihlalin, akademik personelin algıladığı örgütsel desteği azaltıcı etkisi bulunduğu belirlenmiş̧ir. Bu bulgu da literatürdeki benzer çalışmalarla örtüşmektedir (Kiewitz vd., 2009; Suazo, 2009). Dolayısıyla, kendini işine ilişkin inisiyatif sahibi hissetmeyen, kendisini etkileyen kararlarda söz sahibi olduğunu düşünmeyen, kendini geliştirmesi için imkan sunulmayan, yeterince ödüllendirildiğine inanmayan akademik personel, üniversite içinde kendisini daha fazla önemsiz hissetmekte, değersiz görmekte ve üniversitenin desteğinden yoksun olduğunu düşünmektedir.

Bununla birlikte, işlemsel sözleşme unsurlarında algılanan ihlalin örgütsel destek üzerindeki etkisi araştıııldığında ise, üniversitenin çalışanlarına sağladığı faydalara ilişkin yerine getirilmeyen unsurların algılanan örgütsel desteği düşürdüğü, buna karşılık çalışma şartlarında algılanan ihlal ile örgütsel destek arasında bir ilişkinin bulunmadığı belirlenmiştir. Bu bulgu, akademik personelin algıladığı örgütsel destek üzerinde, kendisine sunulan lojman veya kira yardımı, sağlık hizmetleri, eğitim ve gelişim için bireysel ödenekler gibi maddi unsurların da etkisinin bulunduğunu göstermektedir.
Çalışmada psikolojik sözleşme ihlal algısının ilişkisel ve işlemsel unsurlar kapsamında ayrı olarak ele alınmasının ve işten ayrılma niyeti ve algılanan örgütsel destek üzerindeki etkisine ilişkin analizlerin bu ayrım çerçevesinde gerçekleştirilmesinin literatürde yer alan az sayıdaki çalışmaya katkı sağladığı düşünülmektedir. Bununla birlikte çalışmanın, psikolojik sözleşme ihlalinin tutum ve davranışlar üzerindeki olumsuz sonuçlarının ortadan kaldırılması amacıyla kullanılacak örgütsel uygulamalara da yol gösterebileceği düşünülmektedir.

Gerçekleştirilen çalışmanın bazı kısıtları bulunmaktadır. Öncelikle, çalışma yalnızca akademik personel üzerinde gerçekleştirilmiştir. Dolayısıyla farklı devlet kurumlarında ve özel sektör kurumlarında uygulanacak benzer çalışmalar, farklı sonuçların ortaya çıkmasını sağlayabilir. Bununla birlikte akademik personel üzerinde uygulanacak çalışmalar kapsamında, devlet üniversiteleri ile vakıf üniversitelerin karşılaştırılmalı olarak incelenmesi, ihlal algısının derecesinin ve tutum ve davranışlar üzerindeki etkisinin farklı açılardan analiz edilmesini sağlayacaktır.

Çalışma kapsamında belirtilebilecek diğer bir kısıt ise, akademik personel tarafından algılanan psikolojik sözleşme ihlalinin yalnızca işten ayrılma niyeti ve algılanan örgütsel destek üzerindeki etkisinin incelenmiş olmasıdır. Daha sonraki çalışmaların farklı bireysel ve örgütsel çıktılara odaklanarak, psikolojik sözleşme ihlali ile diğer tutum ve davranışlar arasındaki ilişkileri analiz etmesinin faydalı olacağı düşünülmektedir. Bununla birlikte psikolojik sözleşme ihlal algısı ile tutum ve davranışlar arasındaki ilişkiye aracılık ettiği veya ilişkinin yapısını değiştirdiği düşünülen farklı değişkenler çerçevesinde kurulacak modeller, akademik personel açısından psikolojik sözleşme ihlalinin sonuçlarının daha farklı açılardan yorumlanmasına imkan tanıyacaktır. 


\section{KAYNAKLAR}

Anderson, N. ve Schalk, R. (1998) "The Psychological Contract in Retrospect and Prospect" Journal of Organizational Behavior, 19: 637-647.

Argyris, C. (1960) Understanding Organizational Behavior, Homewood, Dorsey Press.

Aselage, J. ve Eisenberger, R. (2003) "Perceived Organizational Support and Psychological Contracts: A Theoretical Integration" Journal of Organizational Behavior, 24(5): 491-509.

Aydın, İ., Memduhoğlu, H.B., Oğuz, E. ve Güngör, S. (2008) "Academic and Non-Academic Staff's Psychological Contract in Turkey" Higher Education Quarterly, 62(3): 252-272.

Brown, T.A. (2006) Confirmatory Factor Analysis for Applied Research, New York, The Guilford Press.

Cammann, C., Fichman, M., Jenkins, G.D. ve Klesh, J. R. (1983) “The Michigan Organizational Assessment Survey: Conceptualization and Instrumentation" Seashore, et al. (eds.) Assessing Organizational Change: A Guide to Methods, Measures and Practices, New York, Wiley Interstice.

Cassar, V. ve Briner, R.B. (2011) “The Relationship between Psychological Contract Breach and Organizational Commitment: Exchange Imbalance as a Moderator of the Mediating Role of Violation" Journal of Vocational Behavior, 78(2): 283-289.

Cho, S., Johanson, M.M. ve Guchait, P. (2009) "Employees Intent to Leave: A Comparison of Determinants of Intent to Leave Versus Intent to Stay" International Journal of Hospitality Management, 28(3): 374-381.

Conway, N. ve Briner, R. B. (2005) Understanding Psychological Contracts at Work: A Critical Evaluation of Theory and Research, New York, Oxford University Press.

Conway, N. ve Coyle-Shapiro, J.A.M. (2012) “The Reciprocal Relationship between Psychological Contract Fulfillment and Employee Performance and the Moderating Role of Perceived Organizational Support and Tenure" Journal of Occupational and Organizational Psychology, 85(2): 1-23.

Coyle-Shapiro, J.A.M. ve Conway, N. (2005) "Exchange Relationships: Examining Psychological Contracts and Perceived Organizational Support" Journal of Applied Psychology, 90(4): 774-781.

Coyle-Shapiro, J. A.M. ve Kessler, I. (2000) "Consequences of the Psychological Contract for the Employment Relationship: A Large Scale Survey" Journal of Management Studies, 37(7): 903-930.
Coyle-Shapiro, J. A.M. ve Kessler, I. (2002) “Exploring Reciprocity through the Lens of the Psychological Contract: Employee and Employer Perspective" European Journal of Work and Organizational Psychology, 11(1): 6986.

Dabos, G.E. ve Rousseau, D.M. (2004) "Mutuality and Reciprocity in the Psychological Contracts of Employees and Employers" Journal of Applied Psychology, 89(1): 52-72.

Eisenberger, R., Armeli, S., Rexwinkel, B., Lynch, P.D. ve Rhoades, L. (2001) "Reciprocation of Perceived Organizational Support” Journal of Applied Psychology, 86(1): 42-51.

Eisenberger, R., Curnmings, J., Armeli, S. ve Lynch, P. (1997) "Perceived Organizational Support, Discretionary Treatment, and Job Satisfaction" Journal of Applied Psychology, 82(5): 812-820.

Eisenberger, R., Huntington, R., Hutchison, S. ve Sowa, D. (1986) "Perceived Organizational Support" Journal of Applied Psychology, 71(3): 500-507.

George, J.M. ve Jones, G.R. (1996) “The Experience of Work and Turnover Intentions: Interactive Value Attainment, Job Satisfaction, and Positive Mood" Journal of Applied Psychology, 81(3): 318-325.

Guest, D.E. (1998) "Is the Psychological Contract Worth Taking Seriously?" Journal of Organizational Behavior, 19: 649-664.

Guest, D.E. (2004) "The Psychology of the Employment Relationship: An Analysis Based on the Psychological Contract" Applied Psychology: An International Review, 53(4): 541-555.

Grimmer, M. ve Oddy, M. (2007) "Violation of the Psychological Contract: The Mediating Effect of Relational Versus Transactional Beliefs" Australian Journal of Management, 32(1): 153-174.

Iverson, R.D. ve Deery, M. (1997) “Turnover Culture in the Hospitality Industry" Human Resource Management Journal, 7(4): 71-82.

Kickul, J. (2001) "Promises Made, Promises Broken: An Exploration of Employee Attraction and Retention Practices in Small Business" Journal of Small Business Management, 39(4): 320-335.

Kickul, J. ve Lester, S.W. (2001) "Broken Promises: Equity Sensitivity as a Moderator between Psychological Contract Breach and Employee Attitudes and Behaviors" Journal of Business and Psychology, 16(2): 191-217. 
Kiefer, T. ve Briner, R.B. (2006) "Emotion at Work" Jackson, P. and Shams, M. (eds.) Developments in Work and Organizational Psychology: Implications for International Business, Oxford, UK, Elsevier Ltd.

Kiewitz, C., Restubog, S.L.D., Zagenczyk T. ve Hochwarter, W. (2009) "The Interactive Effects of Psychological Contract Breach and Organizational Politics on Perceived Organizational Support: Evidence from Two Longitudinal Studies" Journal of Management Studies, 46(5): 806-834.

Levinson, H., Price, C.R., Munden, K.J., Mandl, H.J. ve Solley, C. M. (1962) Men, Management and Mental Health. Cambridge, Harvard University Press.

Millward, L.J. ve Hopkins, L.J. (1998) "Psychological Contracts, Organizational and Job Commitment" Journal of Applied Social Psychology, 28(16): 1530-1556.

Morrison, E.W. ve Robinson, S.L. (1997) "When Employees Feel Betrayed: A Model of How Psychological Contract Violation Develops" Academy of Management Review, 22(1): 226-256.

Nunnally, J.C. ve Bernstein, I.H. (1994) Psychometric Theory, 3rd Edition, New York, McGraw-Hill Inc.

Orvis, K.A., Dudley, N.M. ve Cortina, J.M. (2008) "Conscientiousness and Reactions to Psychological Contract Breach: A Longitudinal Field Study" Journal of Applied Psychology, 93(5): 1183-1193.

Petersitzke, M. (2009) Supervisor Psychological Contract Management, Wissenschaft, Germany, Gabler Edition.

Rhoades, L. ve Eisenberger, R. (2002) "Perceived Organizational Support: A Review of the Literature" Journal of Applied Psychology, 87(4): 698-714.

Robinson, S.L. (1996) "Trust and Breach of the Psychological Contract” Administrative Science Quarterly, 41(4): 574-599.

Robinson, S.L., Kraatz, M.S. ve Rousseau, D.M. (1994) "Changing Obligations and the Psychological Contract: A Longitudinal Study" Academy of Management Journal, 37(1): 137-152.

Robinson, S. L. ve Morrison, E.W. (1995) "Psychological Contracts and OCB: The Effect of Unfulfilled Obligations on Civic Virtue Behavior" Journal of Organizational Behavior, 16(3): 189-298.

Robinson, S.L. ve Rousseau, D.M. (1994) "Violating the Psychological Contract: Not the Exception But the Norm" Journal of Organizational Behavior, 15(3): 245259.

Rousseau, D.M. (1989) "Psychological and Implied Contracts in Organizations" Employee Responsibilities and Rights Journal, 2(2): 121-139.
Rousseau, D.M. (1995) Psychological Contracts in Organizations: Understanding Written and Unwritten Agreements, Thousand Oaks, Sage Publications.

Rusbult, C.E., Farrell, D., Rogers, G. ve Mainous III, A.G. (1988) "Impact of Exchange Variables on Exit, Voice, Loyalty, and Neglect: An Integrative Model of Responses to Declining Job Satisfaction" Academy of Management Journal, 31(3): 599-627.

Schein, E.H. (1965) Organizational Psychology, New Jersey, Prentice-Hall.

Sekaran, U. (1992) Research Methods for Business: A Skill Building Approach, 2nd Edition, New York, John Wiley.

Settoon, R.P., Bennett, N. ve Liden, R.C. (1996) "Social Exchange in Organizations: Perceived Organizational Support, Leader-Member Exchange, and Employee Reciprocity" Journal of Applied Psychology, 81(3): 219-227.

Shore, L.M. ve Tetrick, L.E. (1994) “The Psychological Contract as an Explanatory Framework in the Employment Relationship" Cooper, C. L. and Rousseau, D. M. (eds.) Trends in Organizational Behavior, Vol. 1, Chichester, John Wiley \& Sons.

Shore, L.M. ve Wayne, S.J. (1993) "Commitment and Employee Behavior: Comparison of Affective Commitment and Continuance Commitment with Perceived Organizational Support" Journal of Applied Psychology, 78(5): 774-780.

Steel, R.P. ve Ovalle, N.K. (1984) "A Review and Meta-Analysis of Research on the Relationship between Behavioral Intentions and Employee Turnover" Journal of Applied Psychology, 69(4): 673-686.

Suazo, M.M. (2009) "The Mediating Role of Psychological Contract Violation on the Relations between Psychological Contract Breach and WorkRelated Attitudes and Behaviors" Journal of Managerial Psychology, 24(2): 136-160.

Suazo, M.M., Turnley, W.H. ve Mai-Dalton, R.R. (2005) "The Role of Perceived Violation in Determining Employees' Reactions to Psychological Contract Breach" Journal of Leadership and Organizational Studies, 12(1): 24-36.

Tett, R.P. ve Meyer, J.P. (1993) "Job Satisfaction, Organizational Commitment, Turnover Intention, and Turnover: Path Analyses Based on Meta-Analytic Findings" Personnel Psychology, 46(2): 259-293.

Topa, G.C., Dominguez, J.F.M. ve DePolo, M. (2008) "Psychological Contract Breach and Outcomes: Combining Meta-Analysis and Structural Equation Models" Psicothema, 20(3): 487-496. 
Turnley, W.H., Bolino, C., Lester, S.W. ve Bloodgood, J.M. (2003) "The Impact of Psychological Contract Fulfillment on the Performance of In-Role and Organizational Citizenship Behaviors" Journal of Management, 29(2): 187-206.

Turnley, W.H. ve Feldman, D.C. (1999) "The Impact of Psychological Contract Violations on Exit, Voice, Loyalty, and Neglect" Human Relations, 52(7): 895-922.

Turnley, W.H. ve Feldman, D.C. (2000) "ReExamining the Effects of Psychological Contract Violations: Unmet Expectations and Job Dissatisfaction as Mediators" Journal of Organizational Behavior, 21(1): $25-42$.
Wayne, S.J., Shore, L.M. ve Liden, R.C. (1997) "Perceived Organizational Support and Leader-Member Exchange: A Social Exchange Perspective" Academy of Management Journal, 40(1): 82-111.

Zhang, H.M., Ma, J., Liao, S.Y. ve Wang, S.T. (2010) "A Study on Psychological Contract Breach, Equity Sensitivity and Turnover Intention of Knowledge Workers" 17. International Conference on Management Science and Engineering, Melbourne, Australia, 1002-1007.

Zhao, H., Wayne, S.J., Glibkowski, B C. ve Bravo, J. (2007) "The Impact of Psychological Contract Breach on Work-Related Outcomes: A Meta-Analysis" Personnel Psychology, 60(3): 647-680. 